\title{
Problem Kompatibilitas Pemberian Obat secara Intravena pada Pasien di Intensive Care Unit
}

\section{Compatibility Problems in Intravenous Drug Administration in Intensive Care Unit patients}

\author{
Haqoiroh $^{1}$, Fita Rahmawati ${ }^{2}$, Syed Azhar Syed Sulaiman ${ }^{3}$ \\ malihahanun@yahoo.com \\ ${ }^{1}$ Magister Farmasi Klinik, Universitas Gadjah Mada, Yogyakarta \\ ${ }^{2}$ Fakultas Farmasi, Universitas Gadjah Mada, Yogyakarta \\ ${ }^{3}$ School of Pharmaceutical Sciences, Universiti Sains Malaysia, Malaysia
}

\begin{abstract}
Abstrak
Pemberian obat secara intravena umumnya digunakan pada pasien di rumah sakit yang membutuhkan efek farmakologis cepat atau bila pasien tidak dapat menerima pemberian secara oral. Persiapan pemberian obat intravena perlu kondisi khusus karena ada beberapa risiko yang dapat terjadi seperti inkompatibilitas. Tujuan dari penelitian ini adalah untuk mengetahui prevalensi inkompatibilitas obat intravena pada pasien Intensive Care Units di RSUP Dr. Sardjito dan Rumah Sakit Akademik UGM, dan untuk mengetahui faktor risiko yang mempengaruhi inkompatibilitas obat seperti lama hari perawatan di rumah sakit, jumlah obat-obatan, dan jenis penyakit. Studi ini bersifat cross-sectional, prospektif, dan multisenter di RSUP. Dr. Sardjito dan RS. Akademik UGM, Yogyakarta. Lokasi penelitian ini berada di ICU, ICCU, dan HCU. Prevalensi inkompatibilitas obat dianalisis secara deskripsi dan statistik sedangkan hubungan antara potensi inkompatibilitas dan faktor risiko dianalisis dengan menggunakan uji T-test dan ANOVA dengan interval kepercayaan 95\%. Dari 65 pasien yang didapat dari penelitian ini, prevalensi kejadian inkompatibilitas obat ditemukan pada 28 resep dengan rasio inkompatibilitas 2,4 PI/pasien. Jenis inkompatibilitas yang paling banyak terjadi adalah presipitasi $42(83,35 \%)$, pasangan obat yang paling banyak memicu presipitasi adalah fentanil dan fenitoin; midazolam dan fenitoin. Jumlah obat yang digunakan pasien secara signifikan berpengaruh terhadap inkompatibilitas
\end{abstract}

Kata Kunci : Pemberian Intravena, Inkompatibilitas, Faktor Resiko, Intensive Care Units

\begin{abstract}
Intravenous administration of drugs is commonly used in hospitals patients who need rapid pharmacological effects or when patients can not take oral administration. Preparation for intravenous administration of drugs need special condition because there are some risks include incompatibilities. The aim of this study is to investigate the prevalence of intravenous drug incompatibilities such as drug incompatibilities in Intensive Care Units patients at RSUP Dr. Sardjito and UGM Hospital, and to find the risk factor that affect of drug incompatibilities such as length of hospital stay, number of drugs, and caused of hospitalization. This study was a cross-sectional, prospective,
\end{abstract}


and multicenter in RSUP. Dr. Sardjito and Academic UGM Hospital, Yogyakarta. The location of this study were in ICU, ICCU, and HCU. The prevalence of potential drug incompatibility were analyzed with description statistics and the association between potential incompatibilities and risk factors will be investigated using student $t$ test and ANOVA with 95\% confidence interval. 65 patients were collected from this research. The prevalence of potential drug incompatibilities $(P I)$ were found in 28 prescriptions with ratio PI 2.4 incompatibility/patient. The highest incompatibility type was precipitation of $42(83,35 \%)$ and the most precipitating drug pairs are fentanyl and phenytoin; midazolam and phenytoin. The number of drugs were significantly related with PI.

Keywords : Intravenous administration, Incompatibility, Risk Factor, Intensive Care Units

\section{Pendahuluan}

Kondisi klinis pasien rawat inap umumnya membutuhkan terapi obat intravena. Pemberian obat intravena memerlukan prosedur yang kompleks dan memerlukan kondisi khusus untuk persiapannya (Leal et al., 2016). Pemberian obat secara intravena umumnya digunakan di rumah sakit karena sangat penting bagi pasien yang membutuhkan efek farmakologis yang cepat atau bila ada pasien tidak dapat menerima pengobatan secara oral (Marsilio et al., 2016). Meskipun ada manfaat dari penggunaan pemberian intravena, ada beberapa risiko yang disebabkan oleh pemberian intravena termasuk inkompatibilitas, emboli udara, flebitis, infiltrasi dan ekstravasasi. Salah satu risikonya adalah kemungkinan adanya kemungkinan inkompatibilitas dari obat-obatan yang diberikan bersamaan melalui vena yang sama (Secoli, et al., 2009).

Tidak hanya kemungkinan inkompatibilitas, persiapan atau pemberian intravena yang tidak tepat dapat menyebabkan kerusakan dan kematian pada pasien karena kesalahan pengobatan. Sepupu et al. (2005) melaporkan bahwa kesalahan dalam pemberian intravena berasal dari persiapan yang salah karena pelarut, dosis, atau obat yang salah, dan dapat disebabkan oleh kontaminasi silang. Dalam sebuah penelitian yang dilakukan oleh Vijayakumar dkk. (2014), masalah inkompatibilitas terjadi pada sebagian besar pemberian obat intravena. Inkompatibilitas obat dapat mengganggu stabilitas dan atau efektivitas obat dari $I V$ admixture (Royal College of Nursing, 2010).
Unit Perawatan Intensif (Intensive Care Unit / ICU) adalah sebuah instalasi layanan khusus di rumah sakit dengan kategori perawatan kritis yang menyediakan layanan komprehensif dan berkesinambungan selama 24 jam (Depkes, 2010). Mayoritas pemberian obat pada pasien ICU bersifat parenteral, hal ini dilakukan untuk menjaga konsentrasi obat dalam darah dan pada pasien kritis (Bertsche, 2008). Pemberian obat yang lebih besar selama 24 jam dapat menyebabkan risiko kejadian obat yang merugikan menjadi lebih tinggi, dan kebutuhan akan tindakan medis yang cepat dan responsif mengingat terjadinya kesalahan pengobatan, sehingga inkompaibilitas menjadi masalah yang perlu diperhatikan, terutama pada pemberian obat untuk pasien ICU (Moyen et al., 2009).

Laporan Kesehatan dan Medis dari National Academy Science, Engineering, and Medicine, Amerika Serikat menilai 44.000 sampai 98.000 pasien meninggal setiap tahun karena kesalahan medis (Thomas et al., 2000). Sebuah penelitian di Swiss dilakukan di ruang ICU dewasa menunjukkan $0,7 \%$ kombinasi obat yang digunakan tidak sesuai (Gikic et al., 2000). Inkompatibilitas dalam persiapan parenteral juga terjadi di Indonesia. Dalam sebuah penelitian yang dilakukan oleh Salamah (2016) menunjukkan bahwa potensi inkompatibilitas di Rumah Sakit PKU Muhammadiyah yang ditemukan pada 50 kejadian dari 79 pasien $(0,63$ kejadian per pasien). Bentuk inkompatibilitas didominasi oleh pengendapan dan adsorpsi obat terhadap bahan kemasan.

Persiapan atau pemberian obat yang tidak tepat di Unit Perawatan Intensif (ICU) 
dapat menyebabkan kerugian dan kematian bagi pasien yang menjalani pemberian intravena. Oleh karena itu, penelitian ini bertujuan untuk mengetahui prevalensi problem kompatibilitas dan stabilitas pemberian obat intravena pada pasien Intensive Care Unit di RSUP. Dr. Sardjito dan RS. Akademik UGM dan untuk mengetahui hubungan antara faktor resiko seperti lama hari perawatan, jumlah obat yang digunakan dan jenis penyakit dengan kejadian inkompatibilitas di Intensive Care Units.

\section{Metode Penelitian}

\section{Alat dan Bahan}

Alat yang digunakan dalam penelitian ini adalah rekam medis pasien ICU, ICCU dan HCU yang lengkap, Handbook on Injectable Drugs dan referensi lain seperti jurnal.

\section{Tahapan Penelitian}

Penelitian dilakukan secara prospektif yaitu dengan pengamatan secara visual langsung pada pasien dimulai saat pasien masuk ke ruangan ICU, HCU dan ICCU hingga pasien keluar ruangan. Pengambilan data yang dilakukan adalah dengan cara melihat data rekam medis (RM) pasien, melihat dan mengamati secara langsung obatobatan IV yang diberikan pada pasien di ruangan. Pengamatan dilakukan pada jam pemberian obat, mulai dari proses penyiapan obat yang dilakukan oleh perawat hingga obat diberikan. Data yang diperoleh selanjutnya dilakukan pengecekan dengan buku standar yang digunakan yaitu Handbook on Injectable Drugs atau referensi lainnya.

\section{Analisa Data}

Setelah semua data dikumpulkan maka data akan di analisis menggunakan uji statistik. Analisis secara deskriptif dilakukan untuk mengetahui prevalensi kejadian inkompatibilitas pada sediaan intravena di ICU, ICCU dan HCU. Sedangkan, untuk mengetahui hubungan antara faktor resiko seperti jumlah obat dan lama hari perawatan dengan kejadian inkompatibilitas menggunakan T-test dan dan faktor resiko lain seperti jenis penyakit dengan menggunakan Anova.

\section{Hasil dan Pembahasan}

Hasil dari penelitian ini adalah terdapat 65 pasien yang mendapat perawatan di ICU, HCU dan ICCU. 49 pasien di RSUP. Dr. Sardjito dan 16 pasien di RS. Akademik UGM selama periode penelitian. Jumlah pasien perempuan lebih besar dibandingkan dengan laki-laki pada penelitian ini yakni sebesar $52,3 \%(n=34)$ tidak berbeda jauh dengan lakilaki. Hal ini berbeda dengan penelitian sebelumnya yang menyatakan jumlah pasien laki-laki lebih banyak dibandingkan perempuan (Bertsche et al., 2008; Soares et al., 2017). Sedangkan pada penelitian yang dilakukan oleh Machotka et al. (2014) pasien berjenis kelamin perempuan lebih banyak daripada laki-laki yang dirawat di medical ICU, sedangkan pasien berjenis kelamin laki-laki lebih banyak daripada perempuan di surgical ICU.

Tabel I. Karakteristik Pasien

\begin{tabular}{|c|c|}
\hline Karakteristik Pasien & Jumlah (\%) \\
\hline \multicolumn{2}{|l|}{ Usia } \\
\hline 18-59 tahun & $42(64,6 \%)$ \\
\hline$>60$ tahun & $23(35,3 \%)$ \\
\hline \multicolumn{2}{|l|}{ Jenis kelamin } \\
\hline Laki-laki & $31(47,6 \%)$ \\
\hline Perempuan & $34(52,3 \%)$ \\
\hline \multicolumn{2}{|l|}{ Lama hari perawatan } \\
\hline 1-8 Hari & $39(60 \%)$ \\
\hline$>9$ hari & $26(40 \%)$ \\
\hline $\begin{array}{l}\text { Jumlah obat yang } \\
\text { digunakan }\end{array}$ & \\
\hline 1-2 obat & $14(21,5 \%)$ \\
\hline$>3$ obat & $51(78,4 \%)$ \\
\hline \multicolumn{2}{|l|}{ Jenis Penyakit } \\
\hline Penyakit & $4(6,15 \%)$ \\
\hline Pernafasan & $11(16,92 \%)$ \\
\hline Penyakit Infeksi & $19(29,2 \%)$ \\
\hline Post Operasi & $21(32,3 \%)$ \\
\hline Jantung & $10(15,38 \%)$ \\
\hline Lain-lain & \\
\hline
\end{tabular}

Mayoritas usia pasien adalah 18-59 tahun yakni 64,6\% ( $\mathrm{n}=42)$. Diagnosa pasien masuk ruangan sebagian besar dikarenakan post operasi $(29,2 \%)$, penyakit infeksi $(24.0 \%)$, penyakit pernapasan $(6,15 \%)$, penyakit jantung $(32,3 \%)$, dan lainnya. Jumlah obat $>3$ paling banyak pada digunakan pasien yaitu sebanyak $78,4 \%(\mathrm{n}=51)$. Rata-rata lama hari perawatan pasien yaitu $12,0 \pm 11,5$ hari. 
Pada penelitian ini diperoleh 65 resep obat, jumlah resep dengan potensial inkompatibilitas (PI) sebesar 28 resep yaitu 2.4 $\mathrm{PI} /$ pasien (Tabel II). Pada tabel III dapat dilihat jumlah kejadian pasangan obat intravena ( $\mathrm{n}=408)$ baik yang secara mixture maupun y-site yakni sebesar $209 \quad(51,22 \%)$ pasangan obat kompatibel, 51(12,5\%) pasangan obat inkompatibel dan sebanyak $36,27 \%$ unknown/undocumented. Hasil ini menunjukkan persamaan dengan penelitian sebelumnya, yaitu jumlah pasangan obat yang kompatibel lebih besar dibandingkan dengan pasangan obat yang unknown/undocumented (Gikic dkk., 2000).

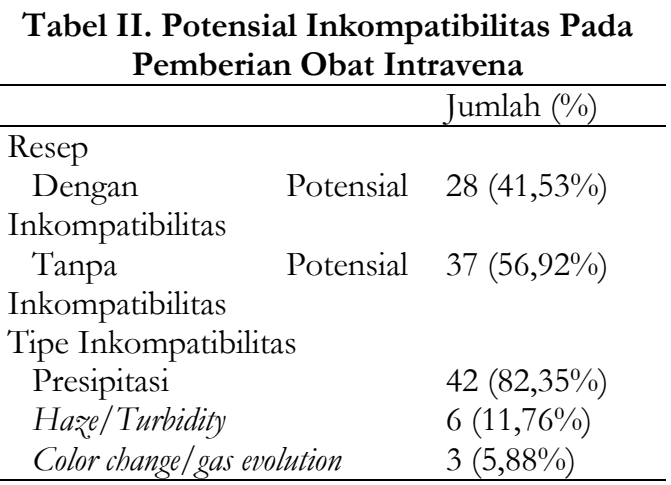

Tipe inkompatibilitas yang terjadi paling besar yaitu presipitasi sebanyak 42 (83,35\%) (Gambar 1), haze/turbidity 11,76\% dan color change/gas evolution 5,88\%. Pasangan obat terbanyak yang menimbulkan presipitasi adalah fentanil dan fenitoin; midazolam dan fenitoin. Kejadian inkompatibilitas terjadi dikarenakan setiap pemberian obat intravena baik sebelum atau sesudah tidak dilakukan flushing dengan menggunakan sterile water for injection (SWFI) atau $\mathrm{NaCl}$ 0.9\% sehingga obat tersebut bercampur pada $y$-site.

Tabel III. Data Kompatibilitas Obat

\begin{tabular}{lllll}
\hline \multirow{2}{*}{ Obat } & \multicolumn{3}{c}{ Kompatibilitas Obat } & Jumlah \\
\cline { 2 - 5 } & $\begin{array}{l}\text { Kom } \\
\text { patibel }\end{array}$ & $\begin{array}{l}\text { Inkom } \\
\text { patibel }\end{array}$ & Unknown \\
\hline Mixture & 209 & 51 & 148 & 408 \\
dan & $(51,22 \%)$ & $(12,5 \%)$ & $(36,27 \%)$ & $(100 \%)$ \\
Y-site & & & & \\
\hline
\end{tabular}

Dari analisis statistik menunjukkan bahwa jumlah obat yang digunakan signifikan mempengaruhi potensi kejadian inkompatibilitas $(p<0,05)$ (Tabel IV). Hasil ini menunjukkan persamaan dengan penelitian sebelumnya yang menyatakan bahwa jumlah penggunaan obat pada pasien merupakan faktor resiko dari kejadian inkompatibilitas pasien (Leal et al., 2016).

\section{Tabel IV. Faktor Resiko Pada Inkompatibilitas Obat}

\begin{tabular}{llll}
\hline Karakteristik & \multicolumn{3}{c}{ PI } \\
\cline { 2 - 4 } Demografi Pasien & $\mathrm{M}$ & SD & P value \\
\hline Lama hari & & & \\
perawatan & & & \\
$\quad$ 1-8 hari & 0,59 & 1,186 & $0,107 \mathrm{~b}$ \\
$\quad>9$ hari & 1,08 & 1,164 & \\
Jumlah obat yang & & & \\
digunakan & & & \\
$\quad$ 1-2 obat & 0,10 & 0,316 & $0,000^{\mathrm{b} *}$ \\
$\quad>3$ obat & 0,91 & 1,251 & \\
Penyakit & & & \\
$\quad$ Penyakit Sistem & 3,57 & 1,144 & $0,404 \mathrm{c}$ \\
Pernafasan & & & \\
$\quad$ Penyakit Infeksi & 2,93 & 1,223 & \\
$\quad$ Post Operasi & 3,13 & 0,835 & \\
$\quad$ Jantung & 2,50 & 0,707 & \\
$\quad$ Lain-lain & 3,00 & 0,000 & \\
\hline p<0,05 & \multicolumn{3}{l}{} \\
b: student's t test; c : Analysis of variance \\
PI : Potensial Inkompatibilitas; \\
M : Mean; \\
SD : Standard deviasi
\end{tabular}

\section{Simpulan}

Terdapat inkompatibilitas pada pasien di ICU, HCU dan ICCU sebanyak 51 (12,5\%) dengan kejadian 2,4PI/pasien. Tipe inkompatibilitas terbanyak yaitu presipitasi $82,35 \%$ yang terjadi pada pasangan obat fentanil dan fenitoin; midazolam dan fenitoin. Jumlah obat intravena yang digunakan pasien signifikan berpengaruh terhadap kejadian inkompatibilitas.

\section{Daftar Pustaka}

Bertsche, T., Mayer, Y., Stahl, R., HoppeTichy, T., Encke, J. \&Haefeli, W. E., 2008. Prevention of Intravenous Drug Incompatibilities in an Intensive Care Unit. Am J Health Syst Pharm, 65(19), 1834-1840.

Leal, K.D.B., Leopoldino, R.W.D., Martins, R.R., dan Veríssimo, L.M., 2016. Potential intravenous drug incompatibilities in a pediatric unit. Einstein (Sao Paulo, Brazil), 14: 185-189.

Marsilio, N.R., da Silva, D., dan Bueno, D., 2016. Drug incompatibilities in the 
adult intensive care unit of a university hospital. Revista Brasileira de Terapia Intensiva, 28: 147-153.

Moyen, E., Camiré, E. dan Stelfox, H.T., 2009. Medication errors in critical care: risk factors, prevention, and disclosure. Canadian Medical Association Journal, 180(9), 936-941.

Royal College of Nursing, 2010, Standards for Infusion Therapy, 3rd Ed., 2, Royal College of Nursing, London.

Secoli S.-R., Figueras A., Lebrão M., Dias de Lima F., Santos J. Risk of potential drug-drug interactions among Brazilian elderly, 2009. Drugs Aging. 27(9):759_ 770 .
Soares, D.B., Nascimento, M.M.G., Rosa, M.B., dan Pereira, M.L., 2017. Incompatibility between intravenous drugs in an adult intensive care unit of a large Brazilian hospital. Journal of Applied Pharmacentical SciencesJAPHAC, 4: 19-27.

Trissel, 2007. Handbook on Injectable Drugs. 17th Edition. American Society of HealthSystem Pharmacists, Bethesda.

Vijayakumar, A., Sharon, E.V., Teena, J., Nobil, S., dan Nazeer, I., 2014. A clinical study on drug-related problems associated with intravenous drug administration. Journal of Basic and Clinical Pharmacy, 5: 49-53 